DOI: $10.17957 / \mathrm{IJAB} / 15.1777$

http://www.fspublishers.org

\title{
Isolation and Evaluation of Bioactive Compounds from Rheum emodi and their Anti-Inflammatory and Anticancer Properties
}

\author{
Sang Koo Park ${ }^{1}$ and Seon Young $\mathbf{~ I m}^{2 *}$ \\ ${ }^{1}$ Food Safety Management Division, Seoul Regional Korea Food and Drug Administration, Seoul 07978, Korea \\ ${ }^{2}$ Department of Crop Science and Biotechnology, Dankook University, Cheonan 31119, Korea \\ *For correspondence: sy_im@dankook.ac.kr \\ Received 24 December 2020; Accepted 18 February 2021; Published 10 May 2021
}

\begin{abstract}
Rheum emodi Wall. ex Meissn is a popular medicinal herb having wide application in traditional medicine for treating of several diseases. The present study was aimed to identify and isolate phytochemicals present in ethyl acetate extract fraction of $R$. emodi and to evaluate the anticancer and anti-inflammatory activities of water/organic solvent fractions and isolated compounds of $R$. emodi rhizome extracts. Based on the structure, flavonoid compound i.e., Myricitrin (sym. Myricetin 3rhamnoside), myricetin 3-galloylrhamnoside and myricetin were identified to be present in ethyl acetate extract. The molecular weight of compound 1 cannot be identified; while compound 5 remained unknown as there was not enough evidence to propose its structure. The isolated compounds and different solvent fractions were tested for their anticancer and antiinflammatory activities. Among Myricetins derivatives, particularly unknown compounds significantly induced the apoptosis and restrained the proliferation of cancer cell lines (A549 and MCF-7) and inhibited the LPS induced NO production (proinflammatory mediator), IL-6 activity, IL-1 $\beta$ and TNF- $\alpha$ (cytokines) activity in RAW 264.7 macrophages in a dose dependent manner and was effective even at lower concentration $(50 \mu \mathrm{g} / \mathrm{mL})$. Similarly, the higher concentration of aqueous and solvent fractions exhibited strong cytotoxic and anti-inflammatory activities. However, water and dichloromethane fractions were most effective in inhibiting the anticancer activities in A549 and MCF-7 cancer cell lines, respectively. At lower concentration (50 and $100 \mu \mathrm{g} / \mathrm{mL}$ ), highest inhibition activity for NO, IL-6 and IL-1 $\beta$ was noted with ethyl acetate fractions and n-Hexane fractions; while water and n-Butanol (fractions) strongly inhibited the TNF- $\alpha$ activity at lower $(100 \mu \mathrm{g} / \mathrm{mL})$ and high $(200$ $\mu \mathrm{g} / \mathrm{mL}$ ) concentration, respectively. In conclusion, the isolated compounds from $R$. emodi rhizome extracts and its rhizome solvent fractions exhibit strong anti-cancer and anti-inflammatory activities and can be used to develop chemotherapeutics and anti-inflammation drugs. (C) 2021 Friends Science Publishers
\end{abstract}

Keywords: Flavonoids; Chemotherapy; Medicinal herb; Bioactive compounds; Macrophages

\section{Introduction}

Inflammation is a defense response of body against injury, pathological infection, noxious stimuli or trauma (Choi et al. 2012). Intense inflammation is often associated with several diseases such as diabetes, arthritis, Alzheimer's and cancer (Pereira and Alvarez-Leite 2014; Torres-Rodríguez et al. 2016; Qian 2017). In response of inflammation macrophages are activated by endotoxin like lipopolysaccharide (LPS). These LPS activated macrophage cells excrete several pro-inflammatory cytokines (tumor necrosis factor- $\alpha$ (TNF- $\alpha)$; interleukin$1 \beta$ (IL-1 $\beta$ ); interleukin-6 (IL-6) and mediators (e.g., free radicals) such as nitric oxide (NO) (Li et al. 2014). Unregulated of excessive production of these mediators involved in arbitrating or exacerbating several diseases such as chronic pulmonary inflammatory disease, arthritis, osteoarthritis, ulcerative colitis and carcinogenesis (Choi et al. 2014).

Cancer (severe metabolic disorder) is one of the major causes of human deaths globally (Iqbal et al. 2017); involves uncontrolled normal cells proliferation caused by genetic instabilities and alterations, which lead to malignant cells generation and metastasis initiation or tissue invasion (Krishnamurthi 2007). At present many therapies for cancer treatment include surgery, chemotherapy and radiotherapy have proved effective in saving lives of numerous cancer patients. Nevertheless, recurrence and severe side effects make these treatments partially effective, pressing the demand for treatments with low toxicity and minimal side effects. Plant derived chemicals compared to chemotherapy drugs are high target specific with low toxicity and can be used to unravel anticancer chemical agents (Cragg and Newman 2007). Rheum (Rheum emodi Wall. ex Meissn) is 
an endemic, perennial, medicinal herb, commonly known as Himalayan Rhubarb; distributed in the Himalayas (subtropical and temperate regions), is widely used as traditional medicine against several diseases (Rokaya et al. 2012). The R. emodi contain several bioactive compounds such as anthraquinones, anthocyanins, flavonoids, stilbenes and desoxyrhapontigenin (Gao et al. 2011) and is known for its strong anti-inflammatory, anticancer, anti-oxidative and antimutagenic effects ( $\mathrm{Li}$ et al. 2008). Among these phytochemicals, flavonoids (cannot synthesized by human and animal) is very important class of compounds which is essential constituent of animal and human diet and possess a therapeutic potential against cancer and inflammation (Raffa et al. 2017).

Few studies have reported that aqueous and methanolic extracts of $R$. emodi found to possess several anticancer (Rajkumar et al. 2011) and anti-inflammatory metabolites (Kounsar and Afzal 2010). However, there is very limited information on the relative efficacy of different organic solvent extracts of $R$. emodi on the anticancer and anti-inflammatory activities. Moreover, the isolation of flavonoids and their anti-inflammatory and anticancer activities in $R$. emodi is not well characterized. Therefore, the present study was carried out to evaluate the in vitro anticancer and anti-inflammatory activities of the rhizome extracts fractions of $R$. emodi using different organic solvents and to isolate and identify the flavonoid compounds from ethyl acetate extracts and to evaluate the anti-inflammatory and anti-cancer potential of isolated compounds.

\section{Materials and Methods}

\section{Plant material}

R. emodi was collected from Langtang at an altitude of 3,500 $\mathrm{m}$ in Nepal. The plant was identified using standard references and authenticated by a botanist. The voucher specimen was deposited in the gene bank of Dankook University.

\section{Chemicals}

LPS (Lipopolysaccharide), DMSO and Griess' reagent for nitrite were procured from Sigma Chemical Co. (St. Louis, MO, USA). The ELISA kit (IL-6, IL-1 $\beta$, TNF- $\alpha$ ) was purchased from BD Biosciences (USA). BHT, L-ascorbic acid, Rutin, Gallic acid, Trizma base, NADH, MTT (3-(4,5dimethylthiazol-2-yl)-2,5-diphenyl tetrazolium bromide), PMS (phenazine methosulphate), NBT (nitroblue tetrazolium), TBA (thiobarbituric acid), TCA (trichloroacetic acid), Trolox (6-hydroxy-2,5,7,8tetramethylchroman-2-carboxylic acid), ammonium thiocyanate and Foli-Ciocalteu's phenol reagent were procured from Sigma Chemical Co. (St. Louis, MO, USA). The HPLC reagents were water, methanol and acetonitrile from J. T. Baker (USA). All other chemicals and solvents were commercial analytical grade.

\section{Extraction and solvent fraction of $R$. emodi}

The air-dried R. emodi rhizomes were crushed in a grinder for $2 \mathrm{~min}$, the process was stopped for $15 \mathrm{~s}$ intervals to prevent samples from heating. The $R$. emodi samples $(800$ g) were extracted with $70 \% \mathrm{EtOH}$ under reflux $(3 \times 2.5 \mathrm{~L}, 2$ $\mathrm{h}$ each time), followed by filtration through filter paper (Whatman No. 2). Later, rotary vacuum-evaporator at $50^{\circ} \mathrm{C}$ under reduced pressure was used to evaporate the solvent of combined extract; while freeze drying helped in removal of remaining water. The crude extract obtained by concentrating the EtOH extract under vacuum was suspended in water and later sequentially extracted with $n$ hexane (room temperature, $2 \times 1 \quad \mathrm{~L}$ ) followed by dichloromethane $(2 \times 1 \mathrm{~L})$, EtOAc $(2 \times 1 \mathrm{~L}), \mathrm{n}-\mathrm{BuOH}(2$ $\times 1 \mathrm{~L}$ ) and water, in order (Fig. S1). The solvents from each step were removed by evaporation and then freezedried. The dried solvent fractions were stored below $18^{\circ} \mathrm{C}$ in deep freezer.

\section{Isolation and identification of bioactive compound}

The method of Lin and Harnly (2007) was followed for identification of phenolic compounds. This protocol obtains mass spectrometric data as negative and positive ionization mode at high $(250 \mathrm{~V})$ and low $(70-100 \mathrm{~V})$ and high excitation energy. The molecular ions are obtained from the negative ionization with low excitation; whereas high energy liberates fragments which show cinnamoyl quinic acids (mono-, di-, or trihydroxy) by successive loss of hydroxy cinnnamoyls. However, UV and MS data and retention time comparison from sample peaks with standards helps in positive compound identification. The method has accumulated a large database of phenolic compounds collected from routine profiling and analysis of standards and is being used for their presence and identification in new plant sources (Lin and Harnly 2007).

\section{Isolation and identification of antioxidant compound by LC-DAD-ESI/MS}

The compounds present in $R$. emodi fractions were isolated using Micromass ZQ MS and an Alliance e2695 HPLC system (Waters Co., Milford, M.A., USA) equipped with a 2998 photodiode array detector in addition to a YMC PACK ODS-AM reversed-phase column $(4.6$ x $250 \mathrm{~nm}$ I.D., $5 \mu \mathrm{m}$; YMC Co. Ltd., Japan). The analysis was conducted at 190-600 nm (the characteristic wavelength of 254, $350 \mathrm{~nm}$ ) detection wavelengths with $1 \mathrm{~mL} / \mathrm{min}$ flow rate and oven temperature of $30^{\circ} \mathrm{C}$. Trifluoroacetic acid $(0.1 \%)$ in water (phase A) and acetonitrile (phase B) were used as mobile phases. The pretreated samples were analyzed by using a gradient of 10 to $30 \%$ of phase B over 
25-min period; $30 \%$ of phase B for five minutes; gradient of 30 to $10 \%$ of phase B for three minutes and then final wash with $10 \%$ phase $\mathrm{B}$ for seven minutes. The electrospray ionization source was used to run the MS analysis in a positive ionization mode and MS parameters were set to 30 $\mathrm{V}$ (cone voltage), $120^{\circ} \mathrm{C}$ (source temperature), $350^{\circ} \mathrm{C}$ (desolvation temperature) and $500 \mathrm{~L} / \mathrm{h}$ (desolvation $\mathrm{N}_{2}$ gas flow). The molecular weight range was $100-1200 \mathrm{~m} / \mathrm{z}$ in the full scan mode.

\section{Preparative antioxidant compounds by LC/MS system}

The analysis protocol was similar to isolation and identification of antioxidant compound by LC-DADESI/MS. In addition, the fractionation parameters were set to maximum fractions and tubes per injection of 78 , solvent front delay of $60 \mathrm{~s}$, spilt/collector delay of $10 \mathrm{~s}$ and maximum fraction width of $60 \mathrm{~s}$. The Ethyl acetate fraction from $R$. emodi with concentration of 50,000 ppm was used for $500 \mu \mathrm{L}$ per injection. In two step purification, the fractionation parameters were different with the first step as fallow: maximum tubes per injection of 114, maximum fraction width of $30 \mathrm{~s}$. The Ethyl acetate fraction from $R$. emodi with concentration of 50,000 ppm was used for 200 $\mu \mathrm{L}$ per injection.

The fractions collected in tubes were directly analyzed without any additional liquid handling. Proper wash of the injection was found to be most important procedure for the proper purity check of collected fractions after preparative purification. Before analytical runs of each series, needle was washed and blank injection with $\mathrm{MeOH} 70 \%$ was used.

Peak purity of collected fractions with their main component was evaluated using relative peak area in mass chromatograms, thus assuming comparable response factor for the impurities and the major component.

\section{Chemical structures of bio active compounds from $R$. emodi}

ChemDraw Ultra 8.0 software (CambridgeSoft, USA) was used for drawing the chemical structures of compounds.

\section{Anti-inflammatory activity assays}

Cell culture: The RAW 264.7 (mouse macrophage cell line) obtained from Korean cell line bank, Seoul, Korea was grown in Dulbecco's modified Eagle's medium having fetal bovine serum (10\%). The macrophages were kept at $37^{\circ} \mathrm{C}$ in humidified atmosphere having $5 \% \mathrm{CO}_{2}$. For the experiment, RAW 264.7 cells were subculture for every $2 \sim 3$ days.

\section{Cell viability}

To evaluate the effect of extracts on the cell viability, cytotoxicity assay was performed. The RAW 264.7 macrophage cell was seeded onto 96-well plate at $10^{4} \sim 10^{5}$ cell/well then cultured in $5 \% \mathrm{CO}_{2}$ incubator at $37^{\circ} \mathrm{C}$ for 24 h. The cells were treated with final concentration of 10,25 and $50 \mu \mathrm{g} / \mathrm{mL}$ of the extracts. The cells were incubated for further $24 \mathrm{~h}$. The medium was exchanged with $180 \mu \mathrm{L}$ fresh medium contained $20 \mu \mathrm{L}$ of $0.5 \mathrm{mg} / \mathrm{mL}$ MTT solution in each well. The absorbance for isolated compounds and solvent extract fractions was measured at 450 and $570 \mathrm{~nm}$ respectively using microplate reader after $1 \sim 4 \mathrm{~h}$.

\section{NO inhibition activity}

The RAW 264.7 macrophage cell was seeded onto 96-well plate at $10^{4} \sim 10^{5} \mathrm{cell} / \mathrm{well}$ then cultured in $5 \% \mathrm{CO}_{2}$ incubator at $37^{\circ} \mathrm{C}$ for $24 \mathrm{~h}$. The cells were incubated in $1 \mu \mathrm{g} / \mathrm{mL}$ of medium containing LPS (Sigma Co.) and final concentration of 10,25 and $50 \mu \mathrm{g} / \mathrm{mL}$ each sample. The cells were incubated for further $24 \mathrm{~h}$. The NO inhibition activity was analyzed by Griess assay. The Griess' regent (0.1\% naphthyethylenediamine and $1 \%$ sulfanilamide in 5\% $\mathrm{H}_{3} \mathrm{PO}_{4}$ solution) was added to each of the supernatant from the cells treated with samples. Sodium nitrite was used as positive control. No contents were read at $540 \mathrm{~nm}$ against a standard sodium nitrite curve.

\section{IL-6, IL-1 $\beta$, and TNF- $\alpha$ inhibition activity}

The RAW 264.7 macrophage cell was seeded onto 96-well plate at $10^{4} \sim 10^{5} \mathrm{cell} /$ well then, cultured in $5 \% \mathrm{CO}_{2}$ incubator at $37^{\circ} \mathrm{C}$ for $24 \mathrm{~h}$. The cell were incubated in a medium containing LPS (Sigma Co.) $1 \mu \mathrm{g} / \mathrm{mL}$ and final concentration 10,25 and $50 \mu \mathrm{g} / \mathrm{mL}$ each samples. The cells were incubated for an additional $24 \mathrm{~h}$. The IL-6, IL-1 $\beta$, TNF- $\alpha$ inhibition activity was analyzed by commercially available ELISA kit (BD OptEIA ${ }^{\mathrm{TM}}$ set Mouse IL-6, IL-1 $\beta$, TNF- $\alpha$ ). The assay was performed as described by the manufacturer's recommendations.

\section{Anticancer activity assays}

Cell culture: Cytotoxicity of the extracts were determined in MCF7 (human breast carcinoma) and A549 (lung carcinoma) from Korean cell line bank, Seoul, Korea, HGF (Human gingival fibroblast) form Department of Dentistry from Dankook University. The cells were kept at $37^{\circ} \mathrm{C}$ in humidified atmosphere containing 5\% $\mathrm{CO}_{2}$; grown in minimum essential medium and RPMI 1640 medium with fetal bovine serum (10\%). The cells were subcultured every $2 \sim 3$ days.

\section{Cytotoxicity assay}

To evaluate effects of extracts on the cell viability, a cytotoxicity assay was performed. The cancer cells (MCF7, A549) were seeded onto 96-well plate at $10^{4} \sim 10^{5}$ cell/well then, cultured in $5 \% \mathrm{CO}_{2}$ incubator at $37^{\circ} \mathrm{C}$ for $24 \mathrm{~h}$ and cells were treated with final concentration 20, 50, 100, 200 
$\mathrm{mg} / \mathrm{mL}$ of extracts. The cells were incubated for further $24 \mathrm{~h}$ and medium was changed with $200 \mu \mathrm{L}$ fresh medium contained $10 \mu \mathrm{L}$ of CCK-8 (Dojindo, Japan) solution in each well. The absorbance was measured at $570 \mathrm{~nm}$ using microplate reader after further $1 \sim 4 \mathrm{~h}$.

\section{Calculation of half maximal inhibitory concentration $\left(\mathrm{IC}_{50}\right)$}

$\mathrm{IC}_{50}$ value, the sample concentration required to scavenge $50 \%$ of the free radicals, were calculated using the percent scavenging activities of the different sample concentrations.

\section{Statistical analysis}

General analysis: The experimental data were analyzed by SPSS (version 12.0 for windows XP, SPSS Inc.) using one and two-way analysis of variance, while Duncan's multiple range test was performed for mean separation $(P<0.05)$.

\section{Multivariate analysis (partial least squares of discriminant analysis (PLS-DA)}

The data matrix was developed by arranging and normalizing all the qualitative and quantitative information, which is used for multivariate statistical analysis as $\log _{10^{-}}$ transformed data. SIMCA-P 11.0 software (Umetrics, Umea, Sweden) was used for performing PLS-DA models.

\section{Results}

\section{Identification of antioxidant compounds}

Five peaks were obtained from ethyl acetate fraction of $R$. emodi based on their retention time and detection wavelength of 190-600 $\mathrm{nm}$ by LC-DAD-ESI/MS. These peaks were separated into compound $1(\mathrm{Rt}=5.30 \mathrm{~min})$, compound $2(\mathrm{Rt}=17.30 \mathrm{~min})$, compound $3(\mathrm{Rt}=23.30$ $\mathrm{min})$, compound $4(\mathrm{Rt}=24.30 \mathrm{~min})$ and compound $5(\mathrm{Rt}=$ $28.30 \mathrm{~min}$ ) using an YMC PACK ODS-AM reversed-phase column (4.6 x $250 \mathrm{~nm}$ I.D., $5 \mu \mathrm{m})$ and narrower range of solvent gradient (Fig. 1).

Compound 1 was identified based on the comparison of retention times, numerous literature sources and mass spectra data of the samples. Retention time of the peak was observed at $4.533 \mathrm{~min}$, revealed a solvent peak. It was not possible to detect the mass even when the LC-DADESI/MS experiment was performed. Likewise, compound 2 was identified using literature sources and mass spectra data of the samples as Myricetin 3-O-rhamnoside (Myricitrin) at the retention time of $17.80 \mathrm{~min}$ through comparison of the retention times, ion was revealed at $464 \mathrm{~m} / \mathrm{z}$ with a molecular formular $\mathrm{C}_{21} \mathrm{H}_{20} \mathrm{O}_{12}$ (Fig. 2). Compound 3 was identified as Myricetin 3-galloylrhamnoside at the retention time at $23.82 \mathrm{~min}$, ion was revealed at $617 \mathrm{~m} / \mathrm{z}$ with a molecular formula of $\mathrm{C}_{28} \mathrm{H}_{24} \mathrm{O}_{16}$ (Fig. 3). Remarkably, this compound was found in this plant for the first time.

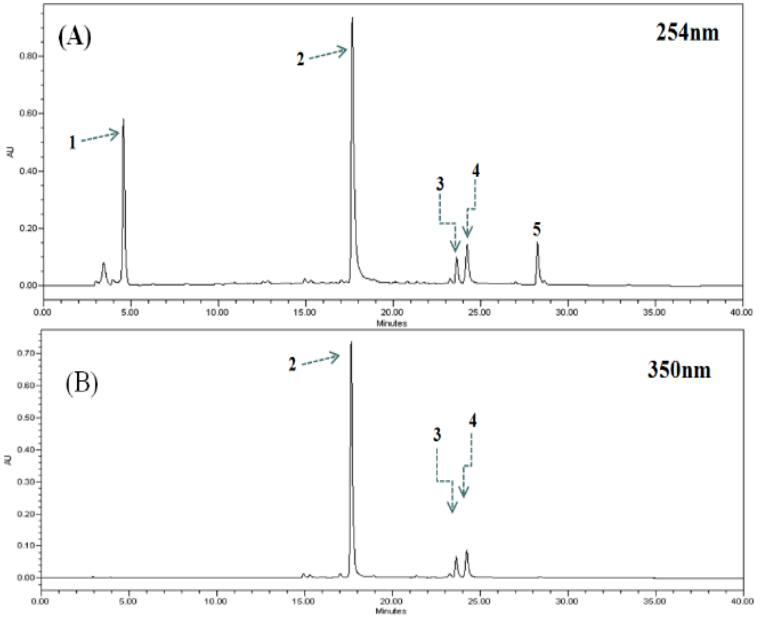

Fig. 1: LC chromatogram (254 $\mathrm{nm}$ and $350 \mathrm{~nm}$ ) of ethyl acetate fraction from $R$. emodi

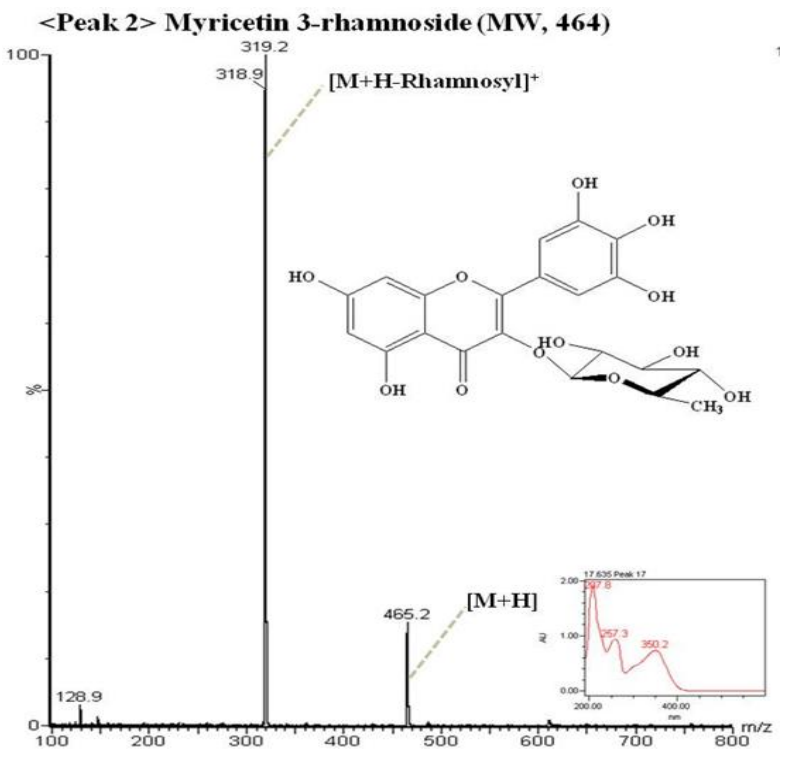

Fig. 2: Structure and MS spectra about compound 1 isolated from R. emodi by LC-DAD-ESI/MS

Compound 4 was identified as Myricetin (Fig. 4), at the retention time of $24.37 \mathrm{~min}$, ion was revealed at $319 \mathrm{~m} / \mathrm{z}$ with a molecular formular of $\mathrm{C}_{15} \mathrm{H}_{10} \mathrm{O}_{8}$. Accordingly, compound 5 was identified as unknown (Fig. 5) at retention time of $28.465 \mathrm{~min}$, ion was revealed at around $520 \mathrm{~m} / \mathrm{z}$. It was not possible to elucidate a structure even when the LCDAD-ESI/MS experiment was performed. There was not enough evidence to propose the structure of the compound. Positive ion electrospray analysis, total ionic current profile and reconstructed ion chromatograms of compound 2-5 (Fig. 2-5) identified the Myricetin derivatives through comparison of retention times and $\mathrm{m} / \mathrm{z}$ values in the total ion current chromatogram from the data gotten from the literature. The ion chromatograms were reconstructed for each value of $\mathrm{m} / \mathrm{z}$ observed for the standard compounds 2 


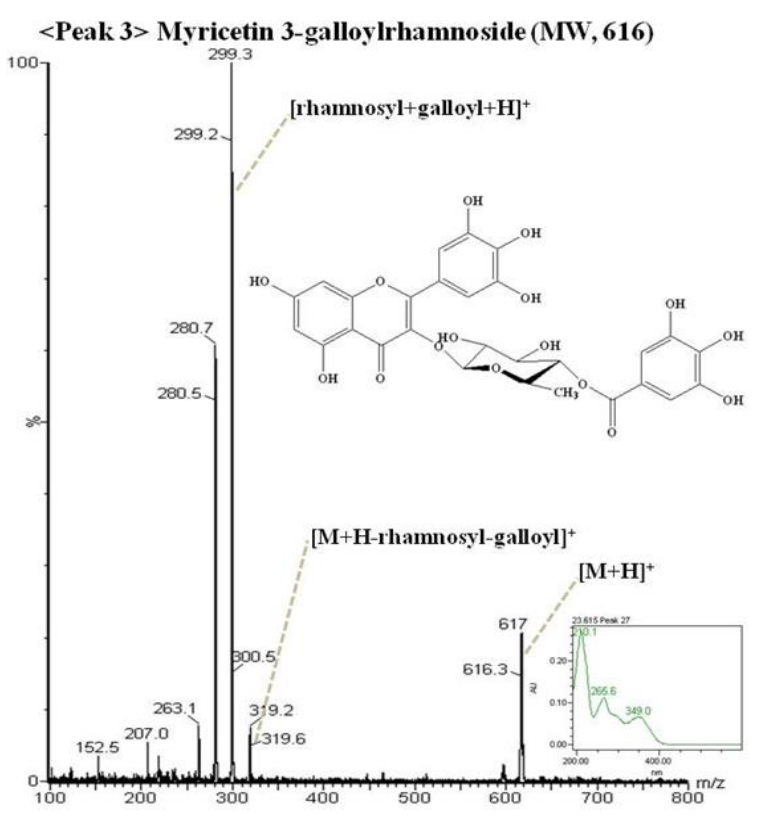

Fig. 3: Structure and MS spectra about compound 2 isolated from $R$. emodi by LC-DAD-ESI/MS

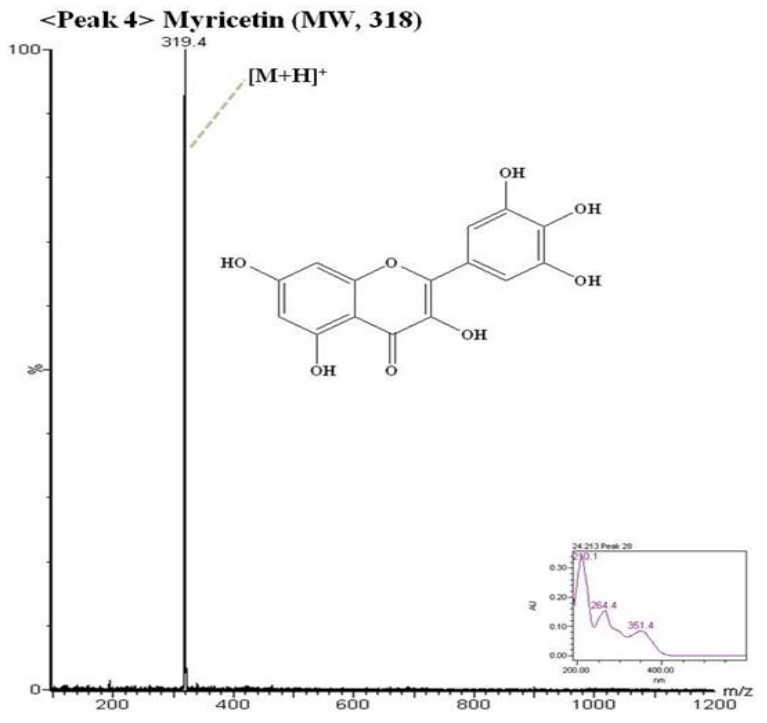

Fig. 4: Structure and MS spectra about compound 3 isolated from $R$. emodi by LC-DAD-ESI/MS

(319 and $464 \mathrm{~m} / \mathrm{z}), 3(280,299,319,465$ and $617 \mathrm{~m} / \mathrm{z})$, and $4(319 \mathrm{~m} / \mathrm{z})$ to advance the separation and the recognition of single compounds. LC-DAD-ESI/MS analysis of compound 2 discovered the presence of myricetin related compounds. Specifically, peaks at $464 \mathrm{~m} / \mathrm{z}$ were observed and the reconstructed ion chromatograms revealed one peak; the value of the mass of the pseudo molecular ion, the retention and the presence in this fraction suggested that these compounds were Rhamnoside $(145 \mathrm{~m} / \mathrm{z})$. The presences of the fragment ion at $463.0853 \mathrm{~m} / \mathrm{z}$ indicate the loss of a galloyl moiety and the presence of myricetin rhamnoside

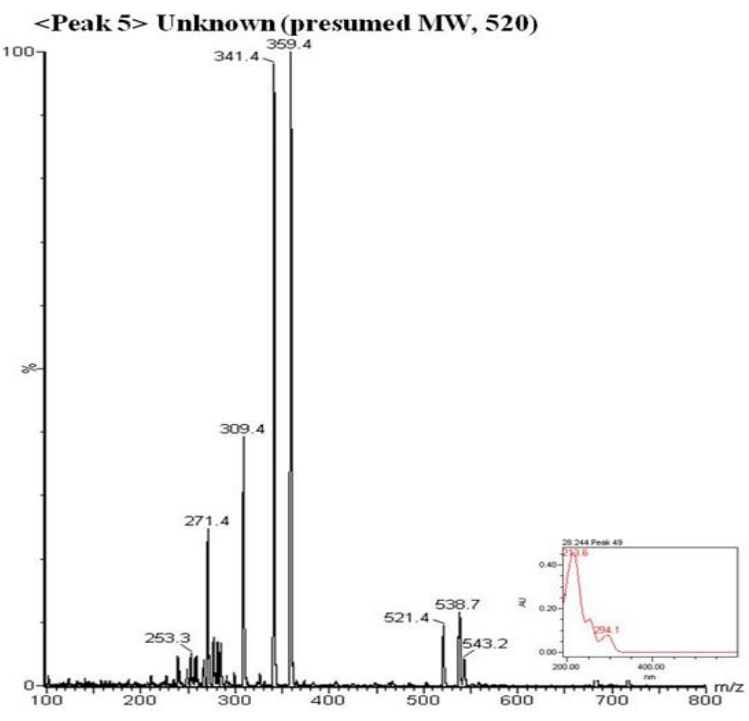

Fig. 5: Structure and MS spectra about compound 4 isolated from $R$. emodi by LC-DAD-ESI/MS

(Amani et al. 2014). The ion at 464, which corresponds to the myricetin $(319 \mathrm{~m} / \mathrm{z})$ and rhamnoside $(145 \mathrm{~m} / \mathrm{z})$, confirmed that this compound had the natural of Myricetin 3-O-rhamnoside (Myricitrin).

The LC-DAD-ESI/MS spectrum of compound 3 gave base peak of the $[\mathrm{M}+\mathrm{H}]^{+}$ion at $617 \mathrm{~m} / z$ and molecular weight 616 . The ion at $617 \mathrm{~m} / z$, which corresponds to the myricetin $(\mathrm{m} / \mathrm{z}$ 464) and galloic acid $(\mathrm{m} / \mathrm{z} 152)$, which eluted at $14.90 \mathrm{~min}$ and showed $615.0988 \mathrm{~m} / \mathrm{z}$, it was confirmed that this compound was characterized as Myricetin 3-Ogalloylrhamnoside according to the MS and MS/MS data and the literature. LC-DAD-ESI/MS analysis of compound 3 revealed the presence of other compounds related to myricetin. Specifically, peaks at $319 \mathrm{~m} / \mathrm{z}$ were identified as myricetin. The LC-DAD-ESI/MS spectrum of compound 3 gave base peak of the $[\mathrm{M}+\mathrm{H}]^{+}$ion at $319 \mathrm{~m} / \mathrm{z}$ and molecular weight of 317. In addition, another fragment was presented at $280 \mathrm{~m} / \mathrm{z}$, which corresponds to the consequent loss of water molecule. Finally, the ion at $299 \mathrm{~m} / z$, which corresponds to the subsequent loss of a rhamnoside (145 $\mathrm{m} / \mathrm{z}$ ) and galloic acid $(152 \mathrm{~m} / \mathrm{z})$, it was confirmed that this compound was the basic structure.

\section{Anticancer activities of $R$. emodi}

Cytotoxic activity of isolated compounds on A549 and MCF-7 cell: The cytotoxic activity on A548 and MCF-7 were performed to estimate the anticancer activity potential of isolated compounds. Doxorubicin was used as a positive control. The $\mathrm{IC}_{50}$ (concentration needed for inhibition of $50 \%$ radical-scavenging effect) was verified from the results of a series of concentration tested. Lower $\mathrm{IC}_{50}$ value corresponds to a greater scavenging activity. The cytotoxic activity on A549 cell lines varied from $\mathrm{IC}_{50} 56.15$ to 67.49 $\mu \mathrm{g} / \mathrm{mL}$ (Table 1). The $\mathrm{IC}_{50}$ values of the cytotoxicity 
Table 1: Comparison of anticancer activity of antioxidant compounds from $R$. emodi in A549 and MCF-7 cells

\begin{tabular}{llr}
\hline Cell Lines & Fraction & $\mathrm{IC}_{50}(\mu \mathrm{g} / \mathrm{mL})$ \\
\hline & Myricetin 3-O-rhamnoside & $64.04 \pm 9.82^{\mathrm{c}}$ \\
A549 & Myricetin 3-O-galloyrhamnoside & $62.21 \pm 6.07^{\mathrm{c}}$ \\
& Myricetin & $67.49 \pm 8.63^{\mathrm{c}}$ \\
& Unknown & $56.15 \pm 9.37^{\mathrm{b}}$ \\
& Doxorubicin* & $41.68 \pm 5.79^{\mathrm{a}}$ \\
& Myricetin 3-O-rhamnoside & $104.76 \pm 11.8^{\mathrm{d}}$ \\
MCF-7 & Myricetin 3-O-galloyrhamnoside & $93.35 \pm 9.09^{\mathrm{c}}$ \\
& Myricetin & $84.35 \pm 8.08^{\mathrm{b}}$ \\
& Unknown & $80.49 \pm 8.39^{\mathrm{b}}$ \\
& Doxorubicin* & $70.17 \pm 4.70^{\mathrm{a}}$ \\
\hline
\end{tabular}

Each value represents means $\pm \mathrm{SD}(\mathrm{n}=3)$
a-d Values within a column followed by different letters are significant different $(P<$ $0.05)$

* Compound used as a positive control

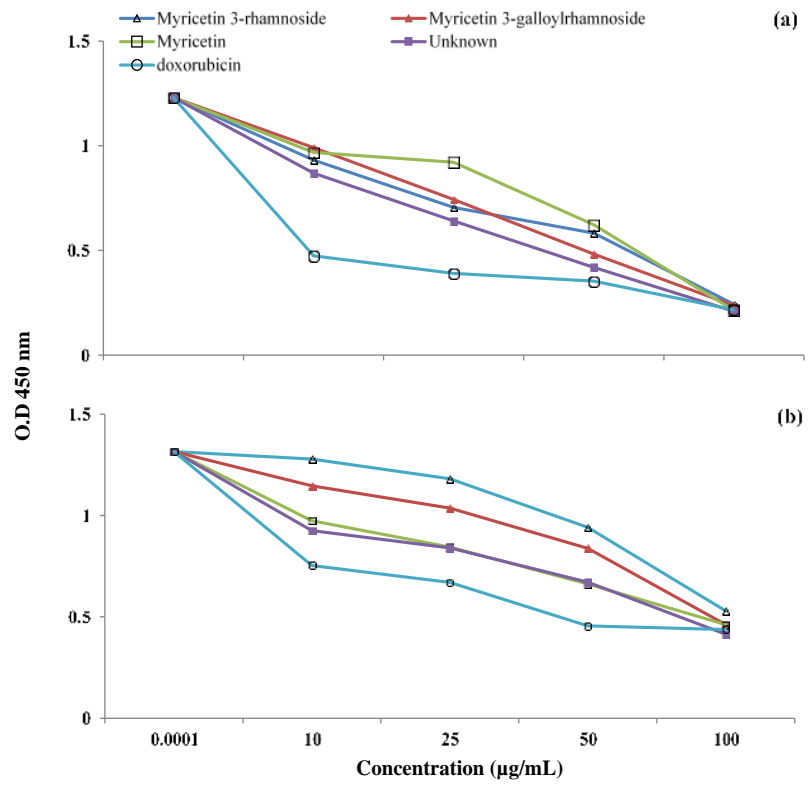

Fig. 6: Cytotoxic activity of isolated compounds from $R$. emodi fractions on (a) A549 and (b) MCF-7 cancer cell lines

activities on A549 cells can be ranked as unknown (56.15 $\mu \mathrm{g} / \mathrm{mL})>$ myricetin 3-galloylrhamnoside $(62.21 \mu \mathrm{g} / \mathrm{mL})>$ Myricetin 3-rhamnoside $(64.04 \mu \mathrm{g} / \mathrm{mL})>$ Myricetin $(67.49$ $\mu \mathrm{g} / \mathrm{mL}$ ) (Table 1). All the compounds exhibited an excellent cytotoxicity activity. However, their $\mathrm{IC}_{50}$ values were greater than that of Doxorubicin $(41.68 \mu \mathrm{g} / \mathrm{mL})$. Unknown compound showed very strong anticancer activity against A549 cells, with an $\mathrm{IC}_{50}$ of $56.15 \mu \mathrm{g} / \mathrm{mL}$. The cytotoxicity activity on A549 cell lines by concentration from compounds were expressed in a dose-dependent manner manner (Fig. 6a). The decrease in absorbance at high dose could be justified by cytotoxicity exhibited by the fractions.

The cytotoxic activity on MCF-7 cell lines varied from $\mathrm{IC}_{50}$ of 80.49 to $104.76 \mu \mathrm{g} / \mathrm{mL}$. The $\mathrm{IC}_{50}$ values of the cytotoxicity activities on MCF-7 cells can be ranked as unknown $(80.49 \mu \mathrm{g} / \mathrm{mL})>$ myricetin $(84.35 \mu \mathrm{g} / \mathrm{mL})>$ Myricetin 3-galloylrhamnoside $(93.35 \mu \mathrm{g} / \mathrm{mL})>$ Myricetin 3-rhamnoside (104.76 $\mu \mathrm{g} / \mathrm{mL})$ (Table 1). Their $\mathrm{IC}_{50}$ values were smaller than that of Doxorubicin $(70.17 \mu \mathrm{g} / \mathrm{mL})$. Unknown showed very strong anticancer activity against A549 and MCF-7 cells. The cytotoxic activities on MCF-7 cell lines by different concentration of compounds were expressed in the dose-dependent (Fig. 6b).

\section{Cytotoxic activity of solvent extract fractions of $R$. emodi on A549 and MCF-7 cells}

The $R$. emodi fractions significantly differed for cytotoxic activity on A549 cells. The $\mathrm{IC}_{50}$ values of $R$. emodi fractions on A549 cell lines and Doxorubicin (positive controls) varied from 74.9 to $128.5 \mu \mathrm{g} / \mathrm{mL}$ (Table 2). The aqueous fraction exhibited the highest cytotoxic activity on A549 cell lines (74.9 $\mu \mathrm{g} / \mathrm{mL})$ followed by dichloromethane $(93.6 \mu \mathrm{g} / \mathrm{mL})>$ $n$-butanol $(104.0 \mu \mathrm{g} / \mathrm{mL})>n$-hexane $(106.14 \mu \mathrm{g} / \mathrm{mL})>$ ethyl acetate $(128.5 \mu \mathrm{g} / \mathrm{mL})$ fractions.

The cytotoxicity activity of $R$. emodi fractions on A549 cell lines increased in the dose-dependent manner. In this regard, the water fraction of $R$. emodi inhibited A549 cell lines growth at 20,50 and $100 \mu \mathrm{g} / \mathrm{mL}$ while $\mathrm{n}$-Hexane showed highest cytotoxicity at $200 \mu \mathrm{g} / \mathrm{mL}$ on A549 cell lines (Fig. S3a).

The cytotoxic activity of $R$. emodi fractions significantly differed against MCF-7 cells. All fractions exhibited lower cytotoxic activity than Doxorubicin (control) $\left(\mathrm{IC}_{50} 50.82 \mu \mathrm{g} / \mathrm{mL}\right.$ ) (Table 2). The cytotoxic activity on MCF-7 cell lines varied from $\mathrm{IC}_{50} 114.72$ to $139.36 \mu \mathrm{g} / \mathrm{mL}$. However, among the tested fractions highest cytotoxic activity was observed for dichloromethane $(114.72 \mu \mathrm{g} / \mathrm{mL})>$ $n$-hexane $(116.34 \mu \mathrm{g} / \mathrm{mL})>$ water $(122.6 \mu \mathrm{g} / \mathrm{mL})>n$ butanol $(124.24 \mu \mathrm{g} / \mathrm{mL})>$ ethyl acetate $(139.36 \mu \mathrm{g} / \mathrm{mL})$ (Table 2). The concentration of fractions on cytotoxicity activity against MCF-7 showed a linear rise with increase in fractions concentration (Fig. S3b). However, the dichloromethane fraction showed higher cytotoxic activity at all concentration than other fractions (Fig. S3a, b).

\section{In vitro cytotoxicity of $R$. emodi fractions on A549 and MCF-7 cells}

The In vitro study revealed that treatment with $50 \mathrm{mg} / \mathrm{mL}$, $100 \mathrm{mg} / \mathrm{mL}$ and $200 \mathrm{mg} / \mathrm{mL}$ fractions dramatically induced black spot in a dose-dependent manner in A549 cells. The viability of A549 cells showed a significant decrease even at high concentration of n-Hexane fraction. The destruction of A549 cells was concentrated at $50 \mathrm{mg} / \mathrm{mL}$ in $\mathrm{n}$-Hexane fraction. The water fraction was found to have the highest cytotoxic activity on A549 cell lines as visible from the destructed nucleus and nuclear compartment at $100 \mathrm{mg} / \mathrm{mL}$ of water fraction (Table 2; Fig. 7).

Treatment of MCF-7 cells with higher concentrations $(50,100$ and $200 \mathrm{mg} / \mathrm{mL})$ of $R$. emodi fractions induced the apoptosis. In this regard, n-Hexane fraction showed a significant inhibition of morphologic changes in MCF-7 cell. 
Charectiazation of anti-inflamatory and cytotoxci activities of R.emodi Wall / Intl J Agric Biol, Vol 25, No 6, 2021

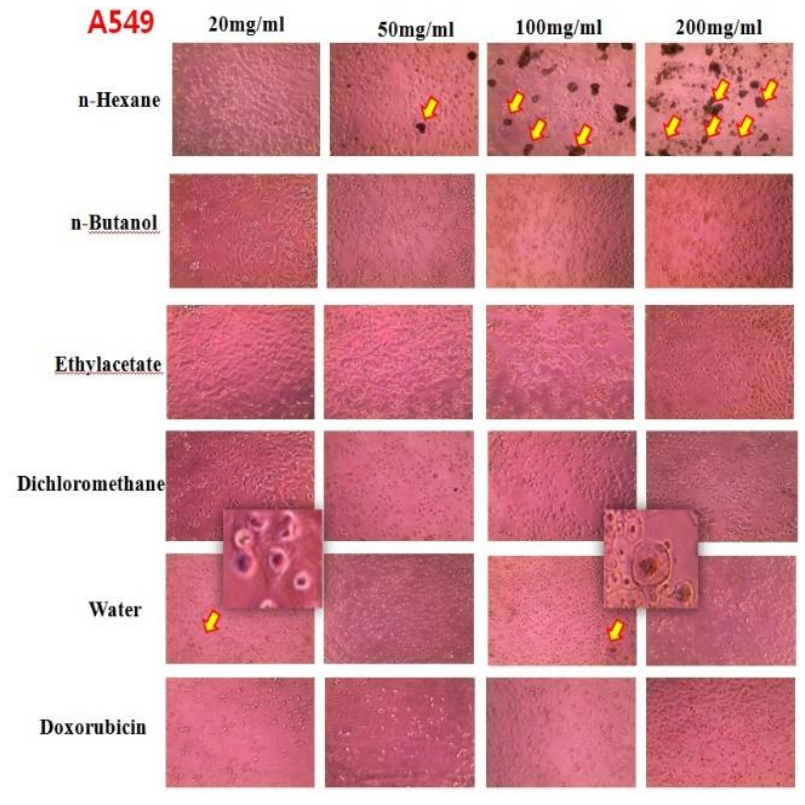

Fig. 7: Cytotoxic activity on A549 cell lines by different concentration of $R$. emodi compound

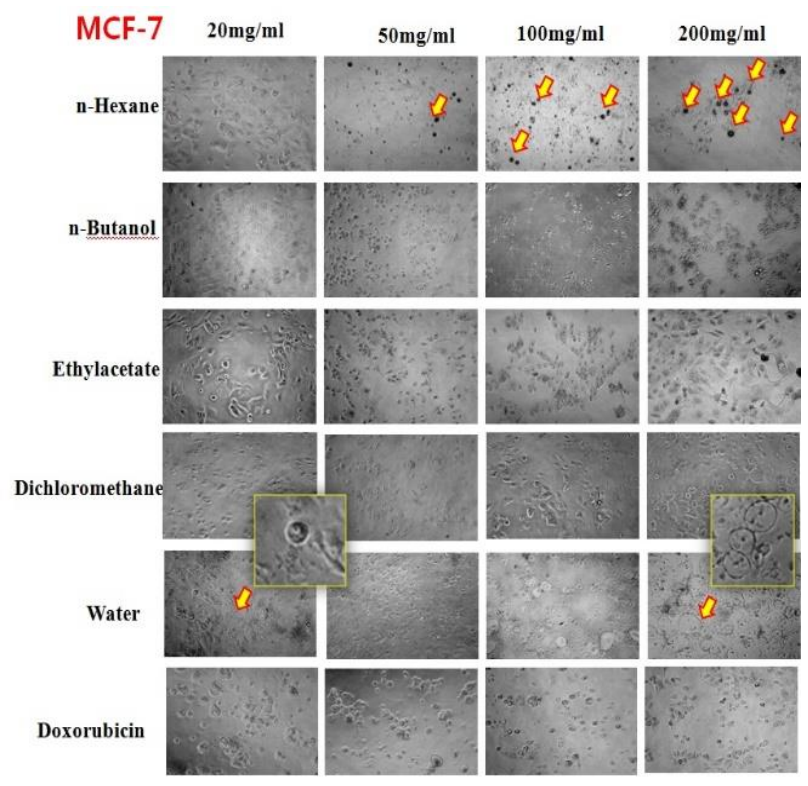

Fig. 8: The Cytotoxic activity of different $R$. emodi fractions on $\mathrm{MCF}-7$ cell lines with different concentration

The data suggest that apoptosis of MCF-7 cancer cells was induced in dose-dependent manner, and these morphologic changes appeared with $50 \mathrm{mg} / \mathrm{mL}$ treatment (Fig. 8).

\section{Anti-inflammatory activities of compounds isolated from R. emodi}

NO inhibition activity: The NO production in the medium of RAW 264.7 cells cultured with LPS was measured in the presence or absence of individual compounds was
Table 2: $\mathrm{IC}_{50}$ values of anticancer activities of Rheum emodi Wall fractions on each cancer cell lines

\begin{tabular}{llr}
\hline Cell & Fraction & $\mathrm{IC}_{50}(\mu \mathrm{g} / \mathrm{mL})$ \\
\hline & n-Hexan & $106.14 \pm 4.42^{\mathrm{c}}$ \\
& n-Butanol & $103.96 \pm 2.56^{\mathrm{c}}$ \\
& Ethylacetate & $128.52 \pm 4.92^{\mathrm{d}}$ \\
& Dichloromethane & $93.58 \pm 2.71^{\mathrm{b}}$ \\
& Water & $74.88 \pm 2.25^{\mathrm{a}}$ \\
& Doxorubicin* & $75.66 \pm 2.88^{\mathrm{a}}$ \\
& n-Hexan & $116.34 \pm 2.47^{\mathrm{bc}}$ \\
& n-Butanol & $124.24 \pm 9.90^{\mathrm{c}}$ \\
MCF-7 & Ethylacetate & $139.36 \pm 7.84^{\mathrm{d}}$ \\
& Dichloromethane & $114.72 \pm 2.99^{\mathrm{b}}$ \\
& Water & $122.68 \pm 6.25^{\mathrm{bc}}$ \\
& Doxorubicin* & $50.82 \pm 1.56^{\mathrm{a}}$ \\
\hline
\end{tabular}

Each value represents means \pm SD

Values within a column for each parameter followed by different letters are significantly different $(P<0.05)$

determined by Greiss reagent assay. The results revealed that individual compounds with concentration of 50, 100 and $200 \mu \mathrm{g} / \mathrm{mL}$ substantially inhibited the LPS-induced NO production in a dose dependent manner (Table 3). The NO inhibition activity from individual compounds varied from 40.6 to $51.3 \mu \mathrm{g} / \mathrm{mL}$ at $50 \mu \mathrm{g} / \mathrm{mL}$ and the myricetin (3) was found to have the highest NO inhibition activity, while at $100 \mu \mathrm{g} / \mathrm{mL}$ myricetin and its derivatives significantly inhibited the NO activity. Likewise, the highest $\mathrm{NO}$ inhibition activity was recorded by Myricetin 3galloylrhamnoside (2) at $200 \mu \mathrm{g} / \mathrm{mL}$ concentration (Table 3). IL-6 inhibition activity of individual compounds: The isolated compounds concentration inhibited LPS-induced IL6 production linearly. In this regard, at $50 \mu \mathrm{g} / \mathrm{mL}$ of isolated compound treatments, mycetrin exhibited the strongest IL-6 inhibition activity; while myricetin 3-galloylrhamnoside (2) showed the most potent IL-6 inhibitory effect with 0.90 $\mu \mathrm{g} / \mathrm{mL}$ at $100 \mu \mathrm{g} / \mathrm{mL}$ concentration compared with the 1.41 $\mu \mathrm{g} / \mathrm{mL}$ of cells were viable after LPS induced stimulation for $24 \mathrm{~h}$ (Table 3). Moreover, higher concentration $(200 \mu \mathrm{g} / \mathrm{mL})$ of isolated compound strongly inhibited the IL-6 activity in macrophages. Among isolated compounds, myricetin (3), myricetin 3-galloylrhamnoside and unknown compound strongly inhibited the LPS induced IL-6 production (Table 3). IL-1 $\beta$ inhibition activity of isolated compounds: The results showed that isolated compounds significantly inhibited LPS-induced IL- $1 \beta$ production in a concentrationdependent manner. Low concentration $(50 \mu \mathrm{g} / \mathrm{mL})$ of isolated compounds possess strong IL-1 $\beta$ inhibition activity potential and at this concentration Myricetin was most effective; while at $100 \mu \mathrm{g} / \mathrm{mL}$ concentration, $576.78 \rho \mathrm{g} / \mathrm{mL}$ of cells unknown viable after LPS induced stimulation for $24 \mathrm{~h}$ and among isolated compounds. Unknown compound strongly inhibited the LPS induced IL-1 $\beta$ production in macrophages. However, Myricetin 3-rhamnoside substantially reduced the cell viability of RAW 264.7 at $200 \mu \mathrm{g} / \mathrm{mL}$ (Table 3).

TNF- $\alpha$ inhibition activity of isolated compounds: The increase in isolated compounds concentration significantly inhibited LPS-induced TNF- $\alpha$ production in a linear pattern. 
Park and Im / Intl J Agric Biol, Vol 25, No 6, 2021

Table 3: Comparison of NO, IL-6, IL-1 $\beta$ and TNF- $\alpha$ inhibition activities of isolated compounds from $R$. emodi on RAW 264.7 cells

\begin{tabular}{|c|c|c|c|c|c|}
\hline \multicolumn{2}{|c|}{$\begin{array}{l}\text { Concentration Compounds } \\
(\mu \mathrm{g} / \mathrm{mL})\end{array}$} & \multirow{2}{*}{$\begin{array}{l}\text { NO inhibition activity } \\
(\mu \mathrm{g} / \mathrm{mL}) \\
51.32 \pm 1.95^{\mathrm{c}}\end{array}$} & \multirow{2}{*}{$\begin{array}{l}\text { IL-6 inhibition activity } \\
(\mu \mathrm{g} / \mathrm{mL})\end{array}$} & \multirow{2}{*}{$\begin{array}{l}\text { IL-1 } \beta \text { inhibition activity } \\
(\rho \mathrm{g} / \mathrm{mL}) \\
256.70 \pm 7.08^{\mathrm{b}}\end{array}$} & \multirow{2}{*}{$\begin{array}{l}\text { TNF- } \alpha \text { inhibition activity } \\
(\rho \mathrm{g} / \mathrm{mL}) \\
553.44 \pm 77.02^{\mathrm{a}}\end{array}$} \\
\hline 50 & Myricetin 3-rhamnoside & & & & \\
\hline & Myricetin 3-galloylrhamnoside & $47.23 \pm 2.05^{\mathrm{bc}}$ & $1.41 \pm 0.02^{\mathrm{b}}$ & $361.43 \pm 7.51^{\mathrm{d}}$ & $657.38 \pm 79.45_{\mathrm{c}}$ \\
\hline & Unknown & $44.58 \pm 4.71^{\mathrm{ab}}$ & $1.37 \pm 0.03^{\mathrm{ab}}$ & $332.41 \pm 6.72^{\mathrm{c}}$ & $618.69 \pm 44.84^{\mathrm{b}}$ \\
\hline \multirow[t]{5}{*}{100} & Myricetin 3-rhamnoside & $21.04 \pm 2.80^{\mathrm{a}}$ & $1.03 \pm 0.14^{\mathrm{b}}$ & $76.79 \pm 0.89^{c}$ & $540.90 \pm 57.84^{b}$ \\
\hline & Myricetin 3-galloylrhamnoside & $21.05 \pm 2.67^{\mathrm{a}}$ & $0.90 \pm 0.26^{\mathrm{a}}$ & $80.96 \pm 2.06^{\mathrm{c}}$ & $458.61 \pm 50.62^{\mathrm{a}}$ \\
\hline & Myricetin & $23.53 \pm 2.10^{\mathrm{a}}$ & $1.00 \pm 0.21^{\mathrm{b}}$ & $67.14 \pm 10.63^{b}$ & $510.33 \pm 12.54^{\mathrm{ab}}$ \\
\hline & Unknown & $27.42 \pm 14.92^{\mathrm{a}}$ & $1.06 \pm 0.13^{\mathrm{b}}$ & $56.16 \pm 5.22^{\mathrm{a}}$ & $461.23 \pm 12.08^{\mathrm{a}}$ \\
\hline & $\operatorname{LPS}(+)^{*}$ & 67.42 & 1.41 & 577.00 & 577.00 \\
\hline \multirow[t]{4}{*}{200} & Myricetin 3-rhamnoside & $4.14 \pm 2.30^{\mathrm{a}}$ & $0.20 \pm 0.05^{\mathrm{b}}$ & $6.63 \pm 0.73^{\mathrm{a}}$ & $343.20 \pm 121.03^{\mathrm{a}}$ \\
\hline & Myricetin 3-galloylrhamnoside & $2.70 \pm 0.10^{\mathrm{a}}$ & $0.11 \pm 0.05^{\mathrm{a}}$ & $30.45 \pm 1.93^{c}$ & $296.72 \pm 109.71^{\mathrm{a}}$ \\
\hline & Myricetin & $3.26 \pm 0.72^{\mathrm{a}}$ & $0.08 \pm 0.01^{\mathrm{a}}$ & $31.52 \pm 1.12^{\mathrm{c}}$ & $381.64 \pm 9.53^{\mathrm{a}}$ \\
\hline & Unknown & $3.46 \pm 0.91^{\mathrm{a}}$ & $0.12 \pm 0.06^{\mathrm{a}}$ & $27.32 \pm 3.30^{\mathrm{b}}$ & $350.33 \pm 5.41^{\mathrm{a}}$ \\
\hline
\end{tabular}

After treatment with $100 \mu \mathrm{g} / \mathrm{mL}$ of the compounds. myricetin 3-galloylrhamnoside (2) exhibited the greatest potent TNF- $\alpha$ inhibitory effect with $458.61 \rho \mathrm{g} / \mathrm{mL}$, compared with the $742.79 \rho \mathrm{g} / \mathrm{mL}$ of cells were viable after LPS induced stimulation for $24 \mathrm{~h}$. The myricetin 3galloylrhamnoside (2) was found to have the highest IL-6 inhibition activity, with $296.71 \mathrm{\rho g} / \mathrm{mL}$ at high concentration (200 $\mu \mathrm{g} / \mathrm{mL})$ followed by: myricetin 3-rhamnoside $(343.20$ $\rho \mathrm{g} / \mathrm{mL})>$ unknown $(350.33 \mathrm{\rho g} / \mathrm{mL})>$ myricetin $(381.64$ $\rho g / \mathrm{mL})$, (Table 3).

\section{Anti-inflammatory activities of solvent extract fractions of $R$. emodi}

NO inhibition activity of $R$. emodi solvent extract fractions on RAW 264.7 cells: The results showed that water and organic solvent fractions with various concentration (50, 100 and $200 \mu \mathrm{g} / \mathrm{mL}$ ) significantly inhibited LPS-induced NO production in a concentrationdependent manner. At the concentration of $50 \mu \mathrm{g} / \mathrm{mL}$, the NO inhibition activity from $R$. emodi fraction varied from 45.0 to $50.1 \mu \mathrm{g} / \mathrm{mL}$. The ethyl acetate fraction (50 $\mu \mathrm{g} / \mathrm{mL}$ ) was found to have the highest NO inhibition activity $(45.04 \mu \mathrm{g} / \mathrm{mL})$; while Dichlloromethane fraction at $200 \mu \mathrm{g} / \mathrm{mL}$ exhibited the strongest $\mathrm{NO}$ inhibition activity $(4.09 \mu \mathrm{g} / \mathrm{mL})$ than rest of the fractions (Table 4$)$. IL-6 inhibition activity of $R$. emodi solvent extract fractions on RAW 264.7 cells: The IL-6 production was measured in the medium of RAW 264.7 cells cultured with LPS in the presence or absence of five fractions. The results showed that all the fractions significantly inhibited LPSinduced IL-6 production in a concentration-dependent manner. However, the response of each fraction varied greatly at different concentration. For instance, at $50 \mu \mathrm{g} / \mathrm{mL}$ ethyl acetate fraction had the highest IL- 6 inhibition activity. Likewise, ethyl acetate and n-Hexane fractions of $R$. emodi exhibited strong IL-6 inhibition activity at $100 \mu \mathrm{g} / \mathrm{mL}$; while in dichloromethane fraction at $200 \mu \mathrm{g} / \mathrm{mL}$ possessed the strongest IL-6 inhibition activity $(0.88 \mu \mathrm{g} / \mathrm{mL})$ (Table 4). The water fraction exhibited the lowest IL-6 inhibition activity compared to all organic solvent fractions at all concentrations.

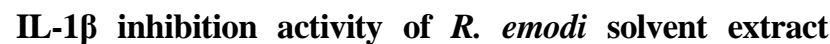
fractions on RAW 264.7cells: All the solvent extract $R$. emodi fractions significantly inhibited LPS-induced IL-1 $\beta$ production in a concentration-dependent manner. The IL-1 $\beta$ inhibition activity of $R$. emodi fraction varied from 159.5 to $201.3 \rho \mathrm{g} / \mathrm{mL}$ at low concentration $(50 \mu \mathrm{g} / \mathrm{mL})$. The ethyl acetate fraction was found to have the highest IL-1 $\beta$ inhibition activity at $50 \mu \mathrm{g} / \mathrm{mL}$; while $\mathrm{n}$-Hexan fraction was most efficient in inhibiting the IL-1 $\beta$ activity at 100 $\mu \mathrm{g} / \mathrm{mL}$. Nevertheless, at high concentration $(200 \mu \mathrm{g} / \mathrm{mL})$ $R$. emodi fractions progressively enhanced the IL- $1 \beta$ inhibition activity and complete inhibition of IL- $1 \beta$ activity in RAW 264.7 cells were observed with dichloromethane fraction (Table 4).

TNF- $\alpha$ inhibition activity of $R$. emodi solvent extract fractions on RAW 264.7cells: The LPS-induced TNF- $\alpha$ production was significantly inhibited by all solvent extract fractions in a concentration-dependent manner. At low concentration $(50 \mu \mathrm{g} / \mathrm{mL})$ there was no significant difference among $R$. emodi fractions for TNF- $\alpha$ inhibition activity, while at $100 \mu \mathrm{g} / \mathrm{mL}$ water fraction substantially enhanced the TNF- $\alpha$ inhibition activity. Moreover, at the concentration of $200 \mu \mathrm{g} / \mathrm{mL}$, the $n$-butanol fraction was found to have the highest TNF- $\alpha$ inhibition activity (309.3 $\rho g / \mathrm{mL}$ ) and possess the strongest anti-inflammatory activity among all other fractions (Table 4).

Classification pattern for isolated compounds and solvent extract fractions of $R$. emodi for their antiinflammatory activities

The individual score showed its pattern, change and cluster formation that contained anti-inflammatory activities of compounds from R. emodi. Accordingly, as shown in Fig. 9, 
Charectiazation of anti-inflamatory and cytotoxci activities of R.emodi Wall / Intl J Agric Biol, Vol 25, No 6, 2021

Table 4: Comparison of NO, IL-6, IL-1 $\beta$ and TNF- $\alpha$ inhibition activities of solvent extract fractions concentrations of $R$. emodi on RAW 264.7 cells

\begin{tabular}{|c|c|c|c|c|c|}
\hline $\begin{array}{l}\text { Concentration } \\
(\mu \mathrm{g} / \mathrm{mL})\end{array}$ & Fraction & $\begin{array}{l}\text { NO inhibition activity } \\
(\mu \mathrm{g} / \mathrm{mL})\end{array}$ & $\begin{array}{l}\mathrm{IL}-6 \\
(\mu \mathrm{g} / \mathrm{mL})\end{array}$ & $\begin{array}{l}\text { IL-1 } \beta \text { inhibition activity } \\
(\rho g / m L)\end{array}$ & $\begin{array}{l}\text { TNF- } \alpha \text { inhibition activity } \\
(\rho g / m L)\end{array}$ \\
\hline \multirow{5}{*}{50} & n-Hexan & $47.25 \pm 1.49^{\mathrm{ab}}$ & $8.04 \pm 2.32^{b}$ & $189.58 \pm 6.54^{\mathrm{a}}$ & $692.54 \pm 49.94$ \\
\hline & n-Butanol & $50.12 \pm 1.34^{\mathrm{b}}$ & $9.19 \pm 1.71^{\mathrm{ab}}$ & $172.41 \pm 36.34^{\mathrm{ab}}$ & $643.52 \pm 31.90$ \\
\hline & Ethylacetate & $45.04 \pm 6.17^{\mathrm{a}}$ & $6.78 \pm 0.95^{\mathrm{a}}$ & $159.46 \pm 36.65^{\mathrm{ab}}$ & $656.48 \pm 105.87$ \\
\hline & Dichloromethane & $47.65 \pm 0.63^{\mathrm{ab}}$ & $9.07 \pm 0.87^{\mathrm{ab}}$ & $201.25 \pm 13.44^{\mathrm{b}}$ & $686.47 \pm 116.91$ \\
\hline & Water & $47.17 \pm 1.78^{\mathrm{ab}}$ & $11.66 \pm 1.97^{\mathrm{c}}$ & $198.39 \pm 7.17^{b}$ & $699.92 \pm 161.45$ \\
\hline \multirow{5}{*}{100} & n-Hexan & $34.60 \pm 8.90$ & $3.83 \pm 0.95^{\mathrm{a}}$ & $27.50 \pm 24.44^{\mathrm{a}}$ & $595.08 \pm 94.86^{\mathrm{b}}$ \\
\hline & n-Butanol & $26.17 \pm 2.34$ & $5.69 \pm 1.01^{\mathrm{b}}$ & $33.13 \pm 8.46^{\mathrm{ab}}$ & $579.18 \pm 46.09^{\mathrm{ab}}$ \\
\hline & Ethylacetate & $26.66 \pm 15.4$ & $3.80 \pm 0.85^{\mathrm{a}}$ & $39.46 \pm 14.05^{\mathrm{ab}}$ & $620.66 \pm 48.97^{b}$ \\
\hline & Dichloromethane & $29.65 \pm 1.00$ & $4.99 \pm 0.71^{\mathrm{ab}}$ & $53.75 \pm 16.41^{\mathrm{bc}}$ & $560.25 \pm 41.26^{\mathrm{ab}}$ \\
\hline & Water & $30.27 \pm 1.18$ & $8.35 \pm 1.10^{c}$ & $65.80 \pm 11.67^{\mathrm{c}}$ & $514.92 \pm 20.87^{\mathrm{a}}$ \\
\hline \multirow{5}{*}{200} & n-Hexan & $7.56 \pm 1.49^{\mathrm{b}}$ & $2.84 \pm 0.47^{\mathrm{c}}$ & $4.64 \pm 1.03^{\mathrm{c}}$ & $468.61 \pm 71.58^{\mathrm{b}}$ \\
\hline & n-Butanol & $6.38 \pm 1.00^{\mathrm{b}}$ & $2.53 \pm 0.53^{\mathrm{c}}$ & $5.27 \pm 1.74^{\mathrm{c}}$ & $309.34 \pm 52.58^{\mathrm{a}}$ \\
\hline & Ethylacetate & $7.51 \pm 1.62^{\mathrm{b}}$ & $1.76 \pm 0.4^{\mathrm{b}}$ & $1.21 \pm 1.13^{\mathrm{ab}}$ & $469.59 \pm 59.31^{\mathrm{b}}$ \\
\hline & Dichloromethane & $4.09 \pm 2.41^{\mathrm{a}}$ & $0.88 \pm 0.30^{\mathrm{a}}$ & $0^{\mathrm{a}}$ & $489.84 \pm 52.04^{b}$ \\
\hline & Water & $6.40 \pm 1.14^{\mathrm{b}}$ & $4.17 \pm 0.69^{\mathrm{d}}$ & $2.23 \pm 1.79^{\mathrm{b}}$ & $470.98 \pm 7.75^{\mathrm{b}}$ \\
\hline
\end{tabular}

Each value represents means \pm SD

values within a column for each concentration followed by different letters are significantly different $(\mathrm{p}<0.05)$

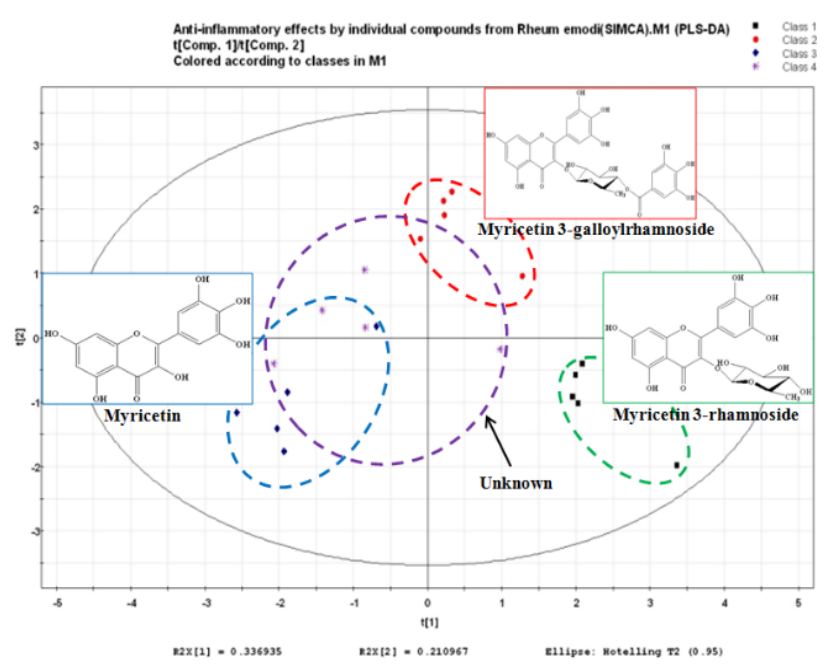

Fig. 9: Score plotting chart of principal component 1 and 2 of the PLS-DA results obtained from the data set by compounds profiling on the anti-inflammatory compounds. This chart showed classification by origin on all samples

(Green circle: Myricetin 3-rhamnoside, Purple circle: Unknown, Red circle: Myricetin- 3-galloylrhamnoside, Blue circle: Myricetin)

the correlation of anti-inflammatory activities and compounds (Myricetin 3-o-rhamnoside, Myricetin 3galloylrhamnoside, Myricetin and unknown) were expressed through PLS-DA score plotting (Fig. 9). They could be grouped in four different groups. The compounds belong to left cluster than the ones on right cluster showed comparably higher anti-inflammatory activities. The cluster for blue color in compound (Myricetin) was located on the left side. The others make cluster for red color in Myricetin 3galloylrhamnoside was located on the top-right side and green color in Myricetin 3-o-rhamnoside was located on the bottom (Fig. 9). As a result, anti-inflammatory activities are related to the structure of compound and its contents, and it meant that the compound belong to myricetin cultivar had higher anti-inflammatory activities that the other compounds belong to Myricetin 3-o-rhamnoside, Myricetin 3-galloylrhamnoside and Unknown cultivars. Also, the Myricetin 3galloylrhamnoside showed that the gallate acylation on the glycoside moiety on a flavonoid had higher antiinflammatory activities than the Myricetin 3-orhamnoside; however, the potency did not exceed the activity of corresponding aglycon.

The correlation of anti-inflammatory activities and fractions (n-Hexan, n-Butanol, Ethyl acetate, Dichloromethane, and water) were expressed through PLSDA score plotting. The fractions belong to right cluster (green and blue circle) showed comparably higher antiinflammatory activity than the ones on left cluster (purple and red circle) showed comparably higher antiinflammatory activities. Especially, it was confirmed that Water and n-Butanol belong to left cluster (yellow green), and Ethyl acetate and Dichloromethane belong to right cluster (yellow), but n-Hexane fraction was mixed up from other fractions (Fig. S4).

\section{Discussion}

The currently used all therapies for cancer treatment, particularly chemical synthesized drugs exhibit significant cytotoxicity to normal cells (Gupta et al. 2013). This study showed the potential of different fractions (organic and aqueous) of $R$. emodi rhizome extracts against anticancer and anti-inflammatory activities. In current study, the aqueous and organic solvent fractions of $R$. emodi exhibited strong anticancer activities. The aqueous and organic solvent extract fractions significantly $(P<0.05)$ enhanced the anticancer activities against A549 and MCF-7 cancer cell lines which can be attributed to the presence of compounds such as 
anthraquinones, polyphenols (flavonoids), antra glycosides etc. in $R$. emodi fractions known for their antifungal, antibacterial and lipid homeostasis activities. Moreover, the activities of $R$. emodi fractions were strongly influenced by the solvent used. These differences in activities of different solvents can be ascribed to existence of distinctive protective metabolites extracted by the different solvents and solubility or stereoselectivity of the fractions (Yu et al. 2002).

Some naturally occurring flavonoids have exhibited selective toxicity to human cancer cells accompanied by very low toxicity to normal cells (Sak 2014). The positive effects of flavonoids in cancer treatment are associated to their strong antioxidant ability, including their capability to scavenge ROS. Several natural flavonoids targets caspases and therefore potent candidate as cancer chemotherapeutic agents (Raffa et al. 2017). One such flavonoid is myricetin (a dietary flavonoid) present in fruits, vegetables, medicinal plants including $R$. emodi (Fig. 1-5; Devi et al. 2015). Myricetin has been found to exert several antitumor roles in various types of cancers which include, antiproliferation, apoptosis induction and anti-metastatic activities (Iyer et al. 2015; Xu et al. 2015; Raffa et al. 2017) In present study, the isolated compounds (Myricetin and its derivatives) from $R$. emodi extracts efficiently inhibited the proliferation and induced the apoptosis in MCF-7 and A549 cancer cells (Table 1 and Fig. 7-8), which can be ascribed to the involvement of myricetin in upregulation of pro-apoptosis proteins and downregulation of ERK1/2 and AKT phosphorylation levels, Bcl-2 protein in cancer cell lines (Raffa et al. 2017; Park et al. 2020) and activation of caspase-3 in cancer cell lines (Raffa et al. 2017). The isolated compounds (myricetin 3-O-rhamnoside, myricetin 3-O-galloyrhamnoside, myricetin and unknown) in present study exhibited the anticancer activities in a dose dependent manner as higher concentration of myricetin exhibit the antiproliferative activities against cancer cells (Sun et al. 2012). Moreover, myricetin reduces the Matrix metalloproteinase 9 (MMP9) (member of MMP family of 24 zinc-dependent endopeptidases involved in induction of pro-IL-1 $\beta$ cleavage and microglial activation) expression showing the antimetastatic effect (Raffa et al. 2017). The present study suggests that the isolated compounds from the $R$. emodi extract can be used as potential cancer therapeutics.

Inflammation is the key part of innate immunity and inflammatory response of a living tissue caused by noxious chemical stimuli, physical injury or infection (Wahab et al. 2018). The acute and chronic inflammation has been treated with different plant extracts in traditional medicine. Here, we observed that the aqueous and organic solvents extract fractions of $R$. emodi inhibited the LPS induced NO production in RAW 264.7 cells. The RAW 264.7 cells are macrophages used for evaluation of anti-inflammatory responses and drug screening (Lee et al. 2014). This inhibition of NO production in macrophage RAW 264.7 cells by $R$. emodi fractions may be accredited to presence of flavonoids in these fractions (Table 4).

These plant extracts often have active constituent of flavonoids and related compounds, which possesses strong anticancer, antiinflammation, antiviral and immunomodulatory activities etc. (Russo et al. 2000; Havsteen 2002). The association of an aromatic ring to heterocyclic ring and functional group oxidation state of heterocyclic ring serves as the bases for flavonoids classification (Beecher 2003). The flavanols are the most abundant flavonoids; usually present in large quantities in vegetables and fruits in the form of aglycone or glycoside including myricetin, quercetin and kaempferol (Shukla et al. 2019). Myricetin (myricetin-3-glucoside, myricetin-3rhamnoside) is an important bioflavonoid known for their anti-inflammatory activities (Table; Fig; Skrovankova et al. 2015). In Raw 264.7 macrophages, LPS induced proinflammatory mediators and cytokines play crucial role in inflammation induction. Nitric oxide (NO) is well known mediator and reacts with superoxide derived from macrophages in response to stimuli and produce cytotoxic peroxynitrite, which is involved in the inflammatory matrix metalloproteinase and cytokines production (Jarvinen et al. 2008). Further, the isolated Myricetin derivatives at higher doses attenuated the NO production (Table 2), which can be ascribed to role of these compounds in iNOS expression downregulation (Cho et al. 2016).

The pro-inflammatory cytokines such as IL-6, IL-1 $\beta$ and TNF- $\alpha$ are well known, which are involved in inflammation induction. Bavia et al. (2015) revealed that LPS induced acute lung injury through increased production of IL-6, IL-1 $\beta$ and TNF- $\alpha$ along with histopathological changes, alveolar wall thickening etc. which can be counteracted by bioactive compounds isolated from plants (Niu et al. 2014). In present study, $R$. emodi solvent extract fractions inhibited the IL-6, IL-1 $\beta$ and TNF- $\alpha$ activity similar to NO in RAW 264.7 macrophage cells (Table 4). Here, all $R$. emodi fractions substantially inhibited the IL-6, IL- $1 \beta$ and TNF- $\alpha$ activities in dose dependent manner. Ethyl acetate was more effective at lower concentration (50 and $100 \mu \mathrm{g} / \mathrm{mL}$ ) for IL-6, IL-1 $\beta$ inhibition activity; while dichloromethane was most effective fractions at higher dose (200 $\mu \mathrm{g} / \mathrm{mL})$ and even complete inhibition of IL-1 $\beta$ activity was observed in RAW 264.7 macrophages. The differential response of these fractions may be due presence of different metabolites in these fractions and their solubility. Furthermore, the compounds (myricetin and its derivatives) isolated from the ethyl acetate fraction substantially inhibited the activities of pro-inflammatory cytokines (IL-6, IL-1 $\beta$ and TNF- $\alpha$ ) (Table 3 ); which can be attributed to Myricetin role in limiting NF- $\kappa \mathrm{B}$ activity through subduing the I $\kappa \mathrm{B} \alpha$ degradation, nuclear translocation of NF- $\kappa \mathrm{B}$ (p65 subunit) and NF- $\mathrm{BB}$ DNA binding activity in LPS stimulated macrophages (RAW264.7) (Cho et al. 2016); as myricetin administration has been testified for inhibition of pro-inflammatory cytokines activities (Niu et al. 2014; Cho 
et al. 2016). Furthermore, the higher antiinflamatory activities of isolated compounds are due to myricetin involvement in HO-1 expression induction via Nrf2 translocation. The isolated compounds (myricetin, myricetin-3-O-galactoside and myricetin-3-O-rhamnoside) from ethyl acetate fraction of $R$. emodi indicate that these compounds can be used for treatment of inflammation disorders.

PLS-DA is much more advantageous to distinguish the characteristics of pre-defined groups compared to the existing PCA (Perez-Enciso and Tenenhaus 2003). PLS-DA is discriminating the assigned cluster characteristics. It is variance that affects the cluster formation or considered as important of compound information. Metabolite analysis data can be visualized through range; standardization and major component score (Cho 2013). The Galloyl flavanol glycosides protect macrophages from the inflammatory response through the limiting the expression of COX-2. The Galloyl group showed enhanced COX-2 expression than their parent compounds (Kim et al. 2004). Although this discrepancy in the results cannot fully be explained at this stage, it may come from different assay system used or, possibly, to the different attachment position of the galloyl group. It can be recognized as the promising flavonoid antiinflammatory with $R$. emodi being a good source of the flavonoids.

\section{Conclusion}

The result of present study showed the potential of aqueous and organic solvent $R$. emodi rhizome fractions and isolated flavanoids for anti-cancer and anti-inflammatory activities. The Flavonoids (myricetins) isolated and identified from ethyl acetate fraction of $R$. emodi exhibited strong cytotoxicity and anti-inflammatory activities on cancer cell lines (MCF-7 and A549) and LPS stimulated macrophages (RAW 264.7), respectively. The higher concentration $(\leq 100$ $\mu \mathrm{M})$ aqueous/organic fractions and isolated compounds strongly inhibited the LPS stimulated TNF- $\alpha$, IL- 6 and IL- $1 \beta$ and NO production in macrophages and induced the apoptosis and restricted the proliferation in cancer cell lines. However, myricetin and unknown compounds were most effective at lower concentration $(50 \mu \mathrm{g} / \mathrm{mL})$ for antiinflammatory and anticancer response, suggesting that the isolated compounds can be used for drug development for cancer and inflammation treatment.

\section{Author Contributions}

Sang KP and SY Im conceived the idea, Sang KP conducted the study, SY Im analyzed the data and prepared the manuscript draft for submission

\section{Conflict of Interest}

The authors delare no conflict of interests

\section{Data Availability}

The data supporting the findings of this study are available within the article and its supplementary materials.

\section{Ehics Approval}

All procedures performed in this study involving human or animal cells were in accordance with the ethical standards of the institution at which the studies were conducted

\section{References}

Amani T, I Iswaldi, D Arráez-Román, A Segura-Carretero, A Fernández-Gutiérrez, M Zarrouk (2014) UPLC-QTOF/MS for a rapid characterisation of phenolic compounds from leaves of Myrtus communis L. Phytochem Anal 25:89-96

Bavia L, IAD Castro, L Isaac (2015). C57BL/6 and A/J mice have different inflammatory response and liver lipid profile in experimental alcoholic liver disease. Mediat Inflamm 2015; Article 491641

Beecher GR (2003). Overview of dietary flavonoids: Nomenclature, occurrence and intake. J Nutr 133:3248-3254

Cho BO, HH Yin, SH Park, EB Byun, HY Ha, SI Jang (2016). Antiinflammatory activity of myricetin from Diospyros lotus through suppression of NF- $\mathrm{BB}$ and STAT1 activation and Nrf2-mediated HO-1 induction in lipopolysaccharide-stimulated RAW264. 7 macrophages. Biosci Biotechnol Biochem 80:1520-1530

Cho YH (2013). Gamma ( $\gamma)$-oryzanol compositions and functional activities in rice genetic resources. Ph.D. Thesis. Chungnam National University, Korea

Choi J, NL Corder, B Koduru, Y Wang (2014). Oxidative stress and hepatic Nox proteins in chronic hepatitis $\mathrm{C}$ and hepatocellular carcinoma. Free Rad Biol Med 72:267-284

Choi WS, PG Shin, JH Lee, GD Kim (2012). The regulatory effect of veratric acid on NO production in LPS-stimulated RAW264.7 macrophage cells. Cell Immunol 280:164-170

Cragg GM, DJ Newman (2007). Plants as a source of anti-cancer agents. $J$ Ethnopharmacol 100:72-79

Devi KP, T Rajavel, S Habtemariam, SF Nabavi, SM Nabavi (2015) Molecular mechanisms underlying anticancer effects of myricetin. Life Sci 142:19-25

Gao LL, XD Xu, HJ Nang, JS Yang, SL Chen (2011). Chemical Constituents in Rheum tanguticum. Chin Trad Herb Drugs 42:443-446

Gupta A, BS Kumar, AS Negi (2013). Current status on development of steroids as anticancer agents. J Ster Biochem Mol Biol 137:242-270

Havsteen B (2002). The biochemistry and medical significance of the flavonoids. Pharmacol Ther 96:67-202

Iqbal J, BH Abbasi, T Mahmood, S Kanwal, B Ali, SA Shah, AT Khalil (2017). Plant-derived anticancer agents: A green anticancer approach. Asian Pac J Trop Biomed 7:1129-1150

Iyer SC, A Gopal, D Halagowder (2015). Myricetin induces apoptosis by inhibiting P21 activated kinase 1 (PAK1) signaling cascade in hepatocellular carcinoma. Mol Cell Biochem 407:223-237

Jarvinen K, K Vuolteenaho, R Nieminen, T Moilanen, RG Knowles, E Moilanen (2008). Selective iNOS inhibitor $1400 \mathrm{~W}$ enhances anticatabolic IL-10 and reduces destructive MMP-10 in OA cartilage. Survey of the effects of $1400 \mathrm{~W}$ on inflammatory mediators produced by OA cartilage as detected by protein antibody array. Clin Exp Rheumatol 26:275-282

Kim HK, GM NA, SU Ye, HS Han (2004). Extraction characteristics and antioxidative activity of Schiznadra chonenesis extracts. Kor J Food Cult 19:484-490

Kounsar F, ZM Afzal (2010). Rheum emodi induces nitric oxide synthase activity in murine macrophages. Amer J Biomed Sci 2:155-162

Krishnamurthi K (2007). 17-screening of natural products for anticancer and antidiabetic properties. Cancer 3:69-75 
Lee J, K Sowndhararajan, M Kim, J Kim, D Kim, S Kim, GY Kim, S Kim, JW Jhoo (2014). Antioxidant, inhibition of $\alpha$-glucosidase and suppression of nitric oxide production in LPS-induced murine macrophages by different fractions of Actinidia arguta stem. Saud $J$ Biol Sci 21:532-538

Li F, SC Wang, X Wang, QY Ren, W Wang, GW Shang, L Zhang, SH Zhang (2008). Novel exploration of cathartic pharmacology induced by rhubarb. Chin J Chin Mater Med 33:481-484

Li YC, YF Xian, ZR Su, SP Ip, JH Xie, JB Liao, DW Wu, CW Li, JN Chen, ZX Lin, XP Lai (2014). Pogostone suppresses proinflammatory mediator production and protects against endotoxic shock in mice. J Ethnopharmacol 157:212-221

Lin LZ, JA Harnly (2007). Screening method for the identification of glycosylated flavonoids and other phenolic compounds using a standard analytical approach for all plant materials. J Agric Food Chem 55:1084-1096

Niu N, B Li, Y Hu, X Li, J Li, H Zhang (2014). Protective effects of scoparone against lipopolysaccharide-induced acute lung injury. Intl Immunopharmacol 23:127-133

Park S, G Song, W Lim (2020). Myricetin inhibits endometriosis growth through cyclin E1 down-regulation in vitro and in vivo. J Nutr Biochem 78:108328

Pereira SS, JI Alvarez-Leite (2014). Low-grade inflammation, obesity, and diabetes. Curr Obes Rep 3:422-431

Perez-Enciso M, M Tenenhaus (2003). Prediction of clinical outcome with microarray data: A partial least squares discriminant analysis (PLSDA) approach. Hum Genet 112:581-592

Qian BZ (2017). Inflammation fires up cancer metastasis. In: Seminars in Cancer Biology, Vol. 47, pp:170-176. Academic Press, London, UK

Raffa D, B Maggio, MV Raimondi, F Plescia, G Daidone (2017). Recent discoveries of anticancer flavonoids. Eur J Med Chem 142:213-228

Rajkumar V, G Guha, RA Kumar (2011). Apoptosis Induction in MDAMB-435S, Hep3B and PC-3 Cell Lines by Rheum emodi rhizome extracts, Asian Pac J Cancer Prevent 12:1197-1200
Rokaya MB, Z Münzbergová, B Timsina, KR Bhattarai (2012). Rheum australe D. Don: A review of its botany, ethnobotany, phytochemistry and pharmacology. $J$ Ethnopharmacol $141: 761-774$

Russo A, R Acquativiva, A Campisi, V sorrenti, CD Giacomo, G Virgata (2000). Bioflavonoids as antiradicals, antioxidants and DNA cleavage protectors. Cell Biol Toxicol 16:91-96

Sak K (2014). Site-specific anticancer effects of dietary flavonoid quercetin. Nutr Cancer 66:177-193

Shukla R, V Pandey, GP Vadnere, S Lodhi (2019). Role of flavonoids in management of inflammatory disorders. In: Bioactive Food as Dietary Interventions for Arthritis and Related Inflammatory Diseases, pp:293-322. Academic Press, London, UK

Skrovankova S, D Sumczynski, J Mlcek, T Jurikova, J Sochor (2015). Bioactive compounds and antioxidant activity in different types of berries. Intl J Mol Sci 16:24673-24706

Sun F, XY Zheng, J Ye, TT Wu, JL Wang, W Chen (2012). Potential anticancer activity of myricetin in human T24 bladder cancer cells both in vitro and in vivo. Nutr Cancer 64:599-606

Torres-Rodríguez ML, E García-Chávez, M Berhow, EGD Mejia (2016). Anti-inflammatory and anti-oxidant effect of Calea urticifolia lyophilized aqueous extract on lipopolysaccharidestimulated RAW 264.7 macrophages. J Ethnopharmacol 188:266-274

Wahab ASM, I Jantan, M Haque, L Arshad (2018). Exploring the leaves of Annona muricata $\mathrm{L}$. as a source of potential anti-inflammatory and anticancer agents. Front Pharmacol 9; Article 661

Xu YC, SWS Leung, GPH Leung, RYK Man (2015). Kaempferol enhances endothelium-dependent relaxation in the porcine coronary artery through activation of large-conductance $\mathrm{Ca}^{2+}$-activated $\mathrm{K}+$ channels. British J Pharmacol 172:3003-3014

Yu L, S Haley, J Perret, M Harris, J Wilson, M Qian (2002). Free radical scavenging properties of wheat extracts. J Agric Food Chem 50:1619-1624 